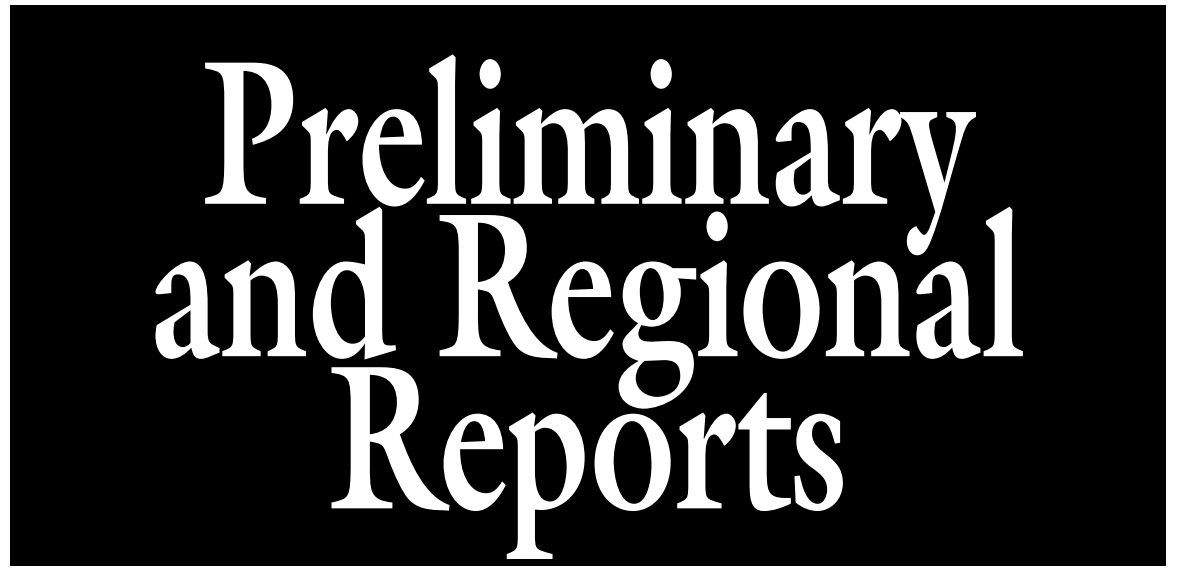

\title{
Exogenous Applications of Moringa Leaf Extract and Cytokinins Improve Plant Growth, Yield, and Fruit Quality of Cherry Tomato
}

\author{
Shahzad M.A. Basra ${ }^{1,2}$ and Carol J. Lovatt ${ }^{1,3}$
}

ADDITIONAL INDEX WORDs. Moringa oleifera, Solanum lycopersicum, abscisic acid, antioxidants, arginine, 6-benzyladenine, lycopene, phenols, proline, protein, sugars, zeatin

SUMMARY. Growth-promoting properties of moringa (Moringa oleifera) leaves were investigated for potential use in crop production by comparing the efficacy of bimonthly foliar and root applications of a moringa leaf extract $[\operatorname{MLE}(3.3 \% \mathrm{w} / \mathrm{v})]$ with the cytokinins 6-benzyladenine (6-BA) and trans-zeatin $(t-Z)$, each at $25 \mathrm{mg} \cdot \mathrm{L}^{-1}$, to increase plant growth, flowering, yield, fruit size, and fruit quality of 'Super Sweet 100' cherry tomato (Solanum lycopersicum). Foliar-applied $t-Z$ and root-applied MLE increased canopy biomass $(P \leq 0.01)$ and root- and foliar-applied MLE increased lateral vegetative shoot number $(P \leq 0.001)$ and plant height $(P \leq$ $\mathbf{0 . 0 0 1}$ ) relative to untreated control plants. Only foliar-applied MLE increased floral shoot number compared with untreated control plants $(P \leq 0.001)$. Plants in all treatments, except root-applied 6-BA, produced more flowers than untreated control plants $(P \leq 0.001)$. Plants receiving root-applied $t-Z$ produced the greatest number of flowers followed by plants receiving root-applied MLE. Cherry tomato plants treated with root-applied $t-Z$ or MLE produced the greatest number of fruit per plant and significantly more than untreated control plants $(P \leq 0.001)$. Foliarapplied 6-BA and MLE and root-applied $t$-Z and MLE increased yield as grams of fruit per plant compared with the untreated control $(P \leq 0.01)$. Foliar- and rootapplied MLE increased fruit concentrations of soluble sugars $(P \leq 0.001)$, protein $(P \leq 0.001)$, antioxidants $(P \leq 0.001)$, and lycopene $(P \leq 0.001)$ compared with fruit from untreated control plants. Foliar- and/or root-applied MLE resulted in the greatest leaf concentrations of protein $(P \leq 0.01)$, proline $(P \leq 0.01)$, arginine $(P \leq 0.01)$, and total antioxidants $(P \leq 0.05)$, which were all significantly greater than the concentrations in leaves from untreated control plants. The results of this single experiment provide evidence suggesting that MLE warrants further research as an inexpensive growth promoter for enhancing tomato plant biomass, yield, and fruit quality, especially in organic crop production, which prohibits the use of many commercial synthetic plant growth regulators.

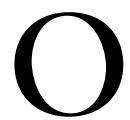
rganic crop production has steadily increased worldwide in response to the increased use of chemicals in agriculture (Paul and Hennig, 2011). In 2011, there were $\approx 37.2$ million hectares committed to organic farming in 160 countries (Paul and Hennig, 2011). During the to increase yield per unit of land to increase grower income and sustain organic commodity-based industries.

Plant growth regulators (PGRs) are powerful tools for solving production problems. However, in the specific case of organic horticultural crop production, use of PGRs remains underdeveloped despite the enormous potential that PGRs offer for maximizing yield, optimizing fruit size and quality, and increasing net dollar return to the grower. In contrast, for a wide variety of conventionally grown horticultural crops, there are many examples of the successful use of commercially available PGRs to solve production problems (Lovatt, 2006). The following examples are all documented uses of PGRs in citriculture (El-Otmani et al., 2000) and are representative of the broad spectrum of PGR uses in horticultural crops. PGRs have been used successfully as foliar sprays to increase flowering, synchronize bloom, or change the time of flowering to avoid adverse climatic conditions or to shift harvest to a time when the market offers a better economic return. Foliar-applied PGRs are routinely used to improve fruit set, reduce June drop, or to prevent preharvest fruit drop to increase yield. PGR sprays are applied to increase fruit size directly by stimulating cell division or to increase fruit size indirectly by reducing fruit number through the application of PGRs that reduce the number of flowers formed or promote flower or fruit abscission. PGRs have been used as both pre- and postharvest treatments to increase the concentrations of nutritive and health-promoting metabolites in the edible portion of the fruit and to hasten or slow the ripening process, color development, and maturation of specific fruit tissues to improve the quality of the product sold in the market. The emerging use of PGRs to overcome the adverse effects of abiotic stress is showing great promise and might benefit production of existing crops that are being negatively impacted by changes in climate (Javid et al., 2011). Surprisingly, these successes have been achieved with a modest number of commercial PGRs that are members of one of the five classic groups of plant hormones: auxins, cytokinins, gibberellins (GAs), abscisic acid (ABA), and ethylene. Hence, the tools needed by the organic 
horticulture industry are known, but remain largely unavailable for use in commercial organic crop production.

In addition, there are only a few commercial PGRs currently labeled for use in conventional tomato production; these include the cytokinin kinetin (X-Cyte ${ }^{\circledR}$; Stoller Enterprises, Houston, TX) at $0.48 \mathrm{~g} \cdot \mathrm{ha}^{-1}$ in a single application to mitigate stress, including frost, drought or excessive moisture, insect or fungus infestation, or herbicide burn, or at $0.96 \mathrm{~g} \cdot \mathrm{ha}^{-1}$ applied in the seedbed to promote seedling emergence, at transplanting to improve plant establishment and again 2 to 3 weeks after bloom to increase fruit set and yield (Stoller Enterprises, n.d). Gibberellic acid $\left[\mathrm{GA}_{3}\right.$ (Activol $^{\circledR}$; Valent BioSciences, Libertyville, IL)] is registered for use on tomato in some European and South American countries, but not in the United States, to promote seedling growth, especially when temperatures are lower than normal, and to increase fruit set and fruit size (Valent BioSciences, 2014). Ethylene released from ethephon (Ethrel ${ }^{\circledR}$; Bayer CropScience, Durham, NC] is used in the field preharvest in many countries, including the United States, to promote earlier and more uniform color development and ripening of tomato fruit for the fresh market or for processing (Bayer CropScience, 2003).

In recent years, there has been significant interest in the growthpromoting potential of leaf extracts of moringa, the most commonly cultivated species in the genus Moringa in the family Moringaceae. It is a fastgrowing, drought-tolerant deciduous tree native to the southern foothills of the Himalayas in northwestern India (Ramachandran et al., 1980). Moringa is widely cultivated in tropical and subtropical areas for its fruit, seeds, and leaves, which are used as vegetables, and its roots, which are used as a condiment reported to taste like horseradish [Armoracia rusticana (Ramachandran, et al., 1980)]. Moringa leaves are rich in ascorbic

The authors thank the Higher Education Commission of Pakistan and the Citrus Research Center and Agricultural Experiment Station of the University of California for financial support.

${ }^{1}$ Department of Botany and Plant Sciences-072, University of California, Riverside, CA 92521-0124

${ }^{2}$ Current address: Department of Crop Physiology, University of Agriculture, Faisalabad, Pakistan

${ }^{3}$ Corresponding author. E-mail: carol.lovatt@ucr.edu. acid, vitamin E, phenols, and essential nutrients that not only benefit human health (Fuglie, 1999; Makkar and Becker, 1996) but also appear to contain cytokinins that improve plant growth (Foidl et al., 2001; Nagar et al., 1982; Nouman et al., 2012). Foidl et al. (2001) demonstrated that MLE increased plant biomass and dry matter content, branching, flowering, and flower retention among a wide variety of plant species. In particular, MLE increased soybean (Glycine max) yield by $35 \%$, although the results with two varieties of black bean (Phaseolus vulgaris) were mixed (Foidl et al., 2001). More recent research provided evidence of the benefits of MLE for improving seed germination, biomass production, and yield of blue panicum grass (Panicum antidotale), barnyard grass (Echinachloa crusgalli), buffel grass (Cenchrus ciliaris), wheat (Triticum aestioum), and maize (Zea mays) (Afzal et al., 2012; Nouman et al., 2012; Yasmeen et al., 2013). In these experiments, MLE also protected maize from low temperature stress (Afzal et al., 2012) and wheat from salinity stress (Yasmeen et al., 2013).

The research presented herein was undertaken to compare the potential benefits of a foliar or root application of MLE with those provided by cytokinins for increasing vegetative growth, yield, and fruit quality components, such as fruit size, of tomato. Tomato is an appropriate test plant because the demand for organically grown tomato fruit has increased with the global increase in tomato consumption to $87.8 \mathrm{~kg}$ per capita in 2014 (Naeve, 2015), commensurate with the discovery of the nutritional value of tomato fruit as a good source of vitamin C, vitamin $\mathrm{A}$, and antioxidants, especially lycopene (Naeve, 2015), and their potential to prevent specific cancers (Giovannucci, 1999). Comprising $15 \%$ of global vegetable production (Garming, 2014), worldwide tomato production in 2014 was 163.4 million tonnes of fruit valued at $\$ 150.3$ billion, with U.S. production at 12.5 million tonnes ( $\$ 11.5$ billion) (Food and Agriculture Organization of the United Nations, 2015).

\section{Materials and methods}

Plant material. Moringa seeds were obtained from a commercial supplier (Moringa Farms California, Sherman Oaks, CA), imbibed overnight between moistened paper towels and then sown in 2.5-gal plastic pots filled with $5 \mathrm{~kg}$ University of California Soil Mix I (Baker, 1957). The pots were placed in a greenhouse at the University of California, Riverside (lat. $33.95^{\circ} \mathrm{N}$, long. $117.40^{\circ} \mathrm{W}$ ), irrigated with half-strength Hoagland's nutrient solution (Hoagland and Arnon, 1950) two times per day and grown under an average $1050 \mu \mathrm{mol} \cdot \mathrm{m}^{-2} \cdot \mathrm{s}^{-1}$ photosynthetic photon flux density (PPFD), measured at a height of $1.5 \mathrm{~m}$ above the pot midday under cloudless conditions with a quantum sensor (LI-COR, Lincoln, NE) at temperatures between $34^{\circ} \mathrm{C}$ maximum and $18{ }^{\circ} \mathrm{C}$ minimum. The following spring, leaves from the 9-month-old plants were used for producing MLE. Young fully expanded (YFE) moringa leaves

\begin{tabular}{cllc}
\hline $\begin{array}{l}\text { Units } \\
\begin{array}{l}\text { To convert U.S. to SI, } \\
\text { multiply by }\end{array}\end{array}$ & U.S. unit & SI unit & $\begin{array}{l}\text { To convert SI to U.S., } \\
\text { multiply by }\end{array}$ \\
\hline 0.4047 & $\mathrm{acre}(\mathrm{s})$ & $\mathrm{ha}$ & 2.4711 \\
29,574 & $\mathrm{fl} \mathrm{oz}$ & $\mu \mathrm{L}$ & $3.3814 \times 10^{-5}$ \\
29.5735 & $\mathrm{fl} \mathrm{oz}$ & $\mathrm{mL}$ & 0.0338 \\
0.3048 & $\mathrm{ft}$ & $\mathrm{m}$ & 3.2808 \\
3.7854 & $\mathrm{gal}$ & $\mathrm{L}$ & 0.2642 \\
2.54 & inch $(\mathrm{es})$ & $\mathrm{cm}$ & 0.3937 \\
25.4 & inch $(\mathrm{es})$ & $\mathrm{mm}$ & 0.0394 \\
0.4536 & $\mathrm{lb}$ & $\mathrm{kg}$ & 2.2046 \\
1 & $\mathrm{micron}(\mathrm{s})$ & $\mu \mathrm{m}$ & 1 \\
28.3495 & $\mathrm{oz}$ & $\mathrm{g}$ & 0.0353 \\
70.0532 & $\mathrm{oz} / \mathrm{acre}$ & $\mathrm{g} \cdot \mathrm{ha}{ }^{-1}$ & 0.0143 \\
1 & $\mathrm{ppb}$ & $\mathrm{ng} \cdot \mathrm{g}^{-1}$ & 1 \\
1 & $\mathrm{ppb}$ & $\mathrm{pg} \cdot \mu \mathrm{L}^{-1}$ & 1 \\
0.1 & $\mathrm{ppm}$ & $\mathrm{mg} / 100 \mathrm{~g}$ & 10 \\
0.001 & $\mathrm{ppm}$ & $\mathrm{mg} \cdot \mathrm{g}^{-1}$ & 1000 \\
1 & $\mathrm{ppm}$ & $\mathrm{mg} \cdot \mathrm{L}^{-1}$ & 1 \\
1 & $\mathrm{ppm}$ & $\mu \mathrm{g} \cdot \mathrm{g}^{-1}$ & 1 \\
0.9072 & $\mathrm{ton}(\mathrm{s})$ & $\mathrm{tonne}(\mathrm{s})$ & 1.1023 \\
$\left({ }^{\circ} \mathrm{F}-32\right) \div 1.8$ & ${ }^{\circ} \mathrm{F}$ & ${ }^{\circ} \mathrm{C}$ & $\left({ }^{\circ} \mathrm{C} \times 1.8\right)+32$ \\
& & &
\end{tabular}


were collected, wrapped in moistened paper towels, transported in a cooler box to the laboratory, and frozen. Frozen leaflets [33 $\mathrm{g}$ fresh weight $(\mathrm{FW})]$ were homogenized in $100 \mathrm{~mL}$ of $80 \%$ ethanol using a tissue homogenizer (Polytron PCU-2; Brinkman Instruments, Westbury, NY) at speed 6, extracted with continuous shaking in a cold room at $4^{\circ} \mathrm{C}$ for $18 \mathrm{~h}$ and then centrifuged at $10,000 \mathrm{~g}_{\mathrm{n}}$ for $10 \mathrm{~min}$ at $4{ }^{\circ} \mathrm{C}$ (RC-5B; Sorvall, Denver, CO) according to Mekonnen (1999) and modified by Basra et al. (2011). The supernatant was decanted, the ethanol was removed using a rotary evaporator (Büchi Labortechnik, Flawil, Switzerland), and the aqueous phase was diluted to a final concentration of $3.3 \%(\mathrm{w} / \mathrm{v})$ and used in the research. Collections of YFE moringa leaves and preparation of MLE continued during the tomato experiment.

Seeds of the hybrid, indeterminate 'Super Sweet 100' cherry tomato were purchased from a commercial company (Botanical Interests, Broomfield, CO), surface sterilized with $1 \%$ commercial bleach for $10 \mathrm{~min}$, rinsed with distilled water, and placed in fully moistened 36-mm peat pellets (Jiffy, Salt Lake City, UT) in plastic trays and placed in a $2.3 \times 1.5 \times 20-\mathrm{m}$ growth chamber (modified PGW 108; Percival, Perry, IA) and maintained at 500 $\mu \mathrm{mol} \cdot \mathrm{m}^{-2} \cdot \mathrm{s}^{-1}$ PPFD at $1.5 \mathrm{~m}$ above the pots at $25^{\circ} \mathrm{C}$ during the 14 -h day and $20{ }^{\circ} \mathrm{C}$ during the 10 -h night. Plants were watered manually with distilled water to maintain uniform moisture ( $\approx 75 \%$ field capacity). After emergence at $10 \mathrm{~d}$ after planting, the plants still in the peat pellets were transplanted into 5 -gal plastic pots filled with $10 \mathrm{~kg}$ University of California Soil Mix I (three plants per pot) and the conditions in the growth chamber were changed to $29^{\circ} \mathrm{C}$ during the 14 -h day and $22^{\circ} \mathrm{C}$ during the 10-h night. Plants were watered manually with half-strength Hoagland's nutrient solution to maintain uniform moisture ( $\approx 75 \%$ field capacity). After 4 weeks, the plants were thinned to one uniform size plant per pot and transferred to a glasshouse. Environmental conditions in the glasshouse ranged between 20 to $30^{\circ} \mathrm{C}$ during the day and 15 to $20{ }^{\circ} \mathrm{C}$ at night; relative humidity was $50 \%$ to $95 \%$; PPFD measured at plant height midday under cloudless conditions with a quantum sensor (LI-COR) ranged between 700 and $1050 \mu \mathrm{mol} \cdot \mathrm{m}^{-2} \cdot \mathrm{s}^{-1}$ during the period of plant growth, flowering, and fruit production. Plants were automatically irrigated on a regular basis with half-strength Hoagland's nutrient solution.

MORINGA LEAF HORMONE CONCENTRATIONS. Young fully expanded moringa leaves were collected in April, May, and June, wrapped in moistened paper towels, and transported in a cooler box to the laboratory, where they were immediately frozen in liquid nitrogen and ground to a fine powder in liquid nitrogen using a mortar and pestle. The ground samples were immediately transferred to $50-\mathrm{mL}$ centrifuge tubes sealed with screw caps and stored in a $-80{ }^{\circ} \mathrm{C}$ freezer until sample collections were completed. The samples were shipped over night on dry ice to the Plant Biotechnology Institute of the $\mathrm{Na}$ tional Research Council of Canada, Saskatoon, SK, Canada (NRCC SK), for determination of the hormone concentrations by high-performance liquid chromatography-electrospray ionization tandem mass spectrometry (HPLC-ESI-MS/MS) with multiple reaction monitoring $(\mathrm{MRM})$ (Waters Corp., Medford, MA) (Ross et al., 2004 ). The procedure for quantification of multiple hormones and metabolites, including indole-3-acetic acid (IAA) and IAA conjugates (IAA-aspartate, IAA-glutamate, IAA-alanine, and IAAleucine), and indole-3-butyric acid (IBA), abscisic acid and its metabolites [phaseic acid (PA), dihydrophaseic acid (DPA), 7' -hydroxy-ABA (7'-OHABA), neo-phaseic acid (neoPA), and ABA-glucose ester (ABAGE)], cytokinins [isopentenyladenine $(2 \mathrm{iP})$, isopentenyladenosine (iPA), trans- and cis-zeatin ( $t$ - and $c$-Z), trans- and ciszeatin riboside ( $t$ - and $c$-ZR), dihydrozeatin (dhZ), dihydrozeatin riboside (dhZR), and trans- and cis-zeatin-Oglucoside ( $t$ - and $c$-ZOG)], and gibberellins, was described in detail by Chiwocha et al. (2003, 2005). Briefly, an aliquot $(100 \mu \mathrm{L})$ containing all the hormone internal standards (ISs), each at a concentration of $0.2 \mathrm{pg} \cdot \mu \mathrm{L}^{-1}$, was added to $50 \mathrm{mg}$ of ground moringa leaf sample followed by $3 \mathrm{~mL}$ of isopropanol:water:glacial acetic acid $(80: 19: 1, \mathrm{v} / \mathrm{v} / \mathrm{v})$. The samples were agitated in the dark for $24 \mathrm{~h}$ at $4{ }^{\circ} \mathrm{C}$ and centrifuged. The supernatant was isolated and dried on a Syncore Polyvap (Büchi Labortechnik) and reconstituted in $100 \mu \mathrm{L}$ of acidifiedmethanol, adjusted to $1 \mathrm{~mL}$ with acidified water, and then partitioned against $2 \mathrm{~mL}$ hexane. After $30 \mathrm{~min}$, the aqueous layer was isolated and dried as above. The dry sample was reconstituted in $800 \mu \mathrm{L}$ of acidifiedmethanol and adjusted to $1 \mathrm{~mL}$ with acidified-water, passed through equilibrated Sep-Pak C18 cartridge (Waters Corp.) and the eluates were dried in a centrifuge vacuum concentrator (Labconco Corp., Kansas City, MO). An IS was prepared with $100 \mu \mathrm{L}$ of the deuterated ISs mixture. A quality control standard (QC) was prepared by adding $100 \mu \mathrm{L}$ of a mixture containing all the analytes of interest, each at a concentration of $0.2 \mathrm{pg} \cdot \mu \mathrm{L}^{-1}$, to $100 \mu \mathrm{L}$ of the IS mix. Finally, the moringa leaf sample, IS, and QC were reconstituted in an aqueous solution of $40 \%$ methanol (v/v), containing $0.5 \%$ acetic acid and $0.1 \mathrm{pg} \cdot \mu \mathrm{L}^{-1}$ of each of the recovery standards, and analyzed by injection onto an ACQUITY UPLC ${ }^{\circledR}$ HSS C18 SB column $(2.1 \times 100 \mathrm{~mm}, 1.8 \mu \mathrm{m}$, Waters Corp. $)$ with an in-line filter and separated by a gradient elution of water containing $0.02 \%$ formic acid against an increasing percentage of a solution of acetonitrile and methanol $(50: 50, \mathrm{v} / \mathrm{v})$. The analysis uses the MRM function of the MassLynx v4.1 control software (Waters Corp.) with the resulting chromatographic traces quantified off-line by the QuanLynx v4.1 software (Waters Corp.). By this method, each trace is integrated and the resulting ratio of signals (non-deuterated/IS) is compared with a previously constructed calibration curve to yield the amount of analyte present (nanograms per sample). Calibration curves were generated from the MRM signals obtained from standard solutions based on the ratio of the chromatographic peak area for each analyte to that of the corresponding IS.

Treatments. Treatments were initiated when the plants were transferred to the glasshouse (38 d after planting). One pot containing one cherry tomato plant was considered one replication with the experiment conducted in a completely randomized design with three replications per treatment. Treatments included the cytokinins 6-BA (Sigma Life Sciences, St. Louis, MO) and $t$-Z (ICN Pharmaceuticals, Costa Mesa, CA), each at $25 \mathrm{mg} \cdot \mathrm{L}^{-1}$, and $\operatorname{MLE}(3.3 \% \mathrm{w} / \mathrm{v})$, which were exogenously applied to 
the foliage of the tomato plants as a fine-droplet spray to give full canopy coverage, but not to runoff $(100 \mathrm{~mL})$, or to the roots as a soil application $(100 \mathrm{~mL})$; control plants were treated with $100 \mathrm{~mL}$ distilled water as a foliar spray or soil application. The treatments were applied every $14 \mathrm{~d}$ (applications to small plants were divided in half and applied over $2 \mathrm{~d}$ ). There were a total of four applications with the last application $14 \mathrm{~d}$ before the final harvest.

TOMATO PLANT BIOMETRICS AND TISSUE ANALYSES. Flowers were counted every week through the final harvest $84 \mathrm{~d}$ after planting. Mature red fruits were harvested six times over a period of $\approx 1$ month starting $\approx 56 \mathrm{~d}$ after planting. After the final fruit harvest, the plants were measured to determine final height and the number of vegetative and floral shoots on each plant were counted, as well the number of flowers remaining on each plant. The relative chlorophyll content of YFE leaves on lateral shoots located at the base of each plant, at $1 / 3$ and $2 / 3$ the height of the plant, and at the apex was determined using a chlorophyll meter (Minolta SPAD-502; Spectrum Technologies, Plainfield, IL), which provides a nondestructive way to measure the relative chlorophyll content (greenness) of leaves (Netto et al., 2005). The values have no units unless standardized with a chemical method for extracting and measuring chlorophyll concentration, such as that of Bruinsma (1963), which was also used in this research for comparison. The YFE leaves were subsequently collected, weighed, processed and analyzed to determine treatment effects on the concentrations of the following metabolites, which were determined spectrophotometrically: chlorophyll $a$ and $b$ and $\beta$-carotene (Bruinsma, 1963), ethanol soluble sugars by the anthrone method (Yemm and Willis, 1954), soluble protein (Bradford, 1976), the free amino acids proline (Chinard, 1952) and arginine by the method of Sakaguchi as described in van Pilsum et al. (1956), total antioxidants using the ferric ion reducing antioxidant power assay (Halvorsen et al., 2002), and total phenols using the FolinCiocalteu method (Spanos and Wrolstad, 1990). The effects of the treatments on the concentrations of the following quality components of fruit from the final harvest were determined spectrophotometrically: total soluble sugars by the anthrone method (Yemm and Willis, 1954), soluble protein (Bradford, 1976), total antioxidants (Halvorsen et al., 2002), lycopene (Agarwal et al., 2001), and total phenols (Spanos and Wrolstad, 1990). The stem of each plant was cut at the soil line and the biomass of the canopy was determined as FW and as dry weight (DW) after oven drying at $60{ }^{\circ} \mathrm{C}$ to a constant weight.

STATISTICAL ANALYsis OF THE DATA. The experiment reported herein was not repeated in space or time and there are no future plans to do so. Mean comparisons were conducted using analysis of variance (ANOVA). When ANOVA testing indicated significant differences, post hoc comparisons were run using Fisher's protected least significant difference procedure with a family error rate of $\alpha \leq 0.05$. The strength of the relationship between two factors was determined by calculating a Pearson's product-moment correlation coefficient. The data were analyzed using the MSTAT-C program (MSTAT Development Team, 1989) or SAS (version 9.2; SAS Institute, Cary, NC).

\section{Results}

EFFECTS OF MLE AND CYTOKININS ON THE REPRODUCTIVE GROWTH OF TOMATO PLANTS. Foliar-applied MLE significantly increased the number of lateral floral shoots produced per cherry tomato plant compared with all other treatments, which was 3.2fold more floral shoots than the untreated control plants $(P \leq 0.001$; Table 1). All treatments significantly increased the total number of flowers produced by the tomato plants through the final harvest ( $84 \mathrm{~d}$ after planting) compared with untreated control plants $(P \leq 0.001$; Table 1$)$. Tomato plants receiving root-applied $t-\mathrm{Z}$ produced the greatest number of flowers (2.2-fold more than untreated control plants), followed by plants treated with root-applied MLE, which produced 2.0-fold more flowers than untreated control plants and an equal number of flowers to plants treated with foliar-applied 6-BA. Plants treated with foliar-applied 6-BA only produced significantly more flowers than tomato plants treated with root-applied 6-BA (1.7-fold more) and untreated control plants (1.8-fold more). On the final harvest date, only plants treated with root-applied MLE had more flowers (3-fold) than the untreated control plants $(P \leq 0.05$; Table 1$)$.
All treatments significantly increased yield as number of fruit per plant compared with the untreated control plants, except root-applied 6-BA ( $P \leq 0.001$; Table 1$)$. The best treatment was root-applied $t-Z$, which significantly increased fruit number per plant above that of plants in all other treatments and 2.1-fold more than untreated control plants. Rootapplied MLE was second best, increasing yield above that of plants in all other treatments, except rootapplied $t-\mathrm{Z}$ and foliar-applied 6-BA, and 1.9-fold more than untreated control plants. All treatments, except foliar-applied $t-Z$ and root-applied 6-BA, significantly increased yield as grams of fruit per plant compared with the untreated control plants: foliar-applied 6-BA, 35\%; foliarapplied MLE, 26\%; root-applied $t-\mathrm{Z}, 38 \%$ and root-applied MLE, 37\% $(P \leq 0.01$; Table 1$)$. The weight of individual fruit decreased progressively with each harvest, from $7.5 \mathrm{~g}$ per fruit averaged across all treatments at the first harvest to only $3.1 \mathrm{~g}$ per fruit at the sixth harvest $[P \leq 0.0001$ (data not shown)]. The weight of individual fruit was significantly increased by foliar- or root-applied MLE at both the second $(P \leq 0.0796)$ and fifth $(P \leq$ 0.0203 ) harvests (data not shown). Foliar-applied MLE tended to increase fruit size averaged across the six harvests $(44 \%)$ above that of fruit from untreated control plants but the effect was only significant at the $10 \%$ confidence level (Table 1).

EFFECTS OF MLE AND CYTOKININS ON THE VEgETATIVE GROWTH OF TOMATO PLANTS. Root-applied MLE and foliar-applied $t-\mathrm{Z}$ were the only two treatments that significantly increased the final canopy biomass of the tomato plants as both FW and DW above that of untreated control plants, a net increase of $74 \%$ and $61 \%$ in FW, respectively, and $42 \%$ and $35 \%$ in DW, respectively $(P \leq 0.01$; Table $2)$. Plants treated with root-applied MLE produced significantly more canopy biomass (FW and DW) than plants in all other treatments, except those receiving foliar-applied $t-\mathrm{Z}(P \leq$ $0.01)$. The number of lateral vegetative shoots per plant was dramatically increased in response to root-applied MLE (2.7-fold), foliar-applied MLE (2.2-fold), and root-applied $t$-Z (1.8fold) compared with untreated control plants $(P \leq 0.001$; Table 2$)$. However, 
Table 1. Effects of four bimonthly $100-\mathrm{mL}(3.38 \mathrm{fl} \mathrm{oz})$ foliar or root applications of moringa leaf extract (MLE) (3.3\% w/v) and cytokinins $\left[25 \mathrm{mg} \cdot \mathrm{L}^{-1}(\mathrm{ppm})\right]$ on the productivity of cherry tomato plants as total number of flowers, lateral floral shoots, flowers at the final harvest (84 $\mathrm{d}$ after planting), and total yield and average fruit weight for six harvests.

\begin{tabular}{|c|c|c|c|c|c|c|}
\hline Treatments & $\begin{array}{l}\text { Total flowers } \\
\text { (no./plant) }\end{array}$ & $\begin{array}{c}\text { Total floral shoots } \\
\text { (no./plant) }\end{array}$ & $\begin{array}{c}\text { Final flowers } \\
\text { (no./plant) }\end{array}$ & $\begin{array}{l}\text { Total fruit } \\
\text { (no./plant) }\end{array}$ & $\begin{array}{l}\text { Total yield } \\
(\mathrm{g} / \text { plant })^{\mathrm{z}}\end{array}$ & $\begin{array}{c}\text { Fruit wt } \\
\text { (g/fruit FW) }\end{array}$ \\
\hline Control-None & $175.0 \mathrm{~d}^{\mathrm{y}}$ & $28.0 \mathrm{~b}$ & $52.3 \mathrm{bc}$ & $153.0 \mathrm{e}$ & $641.8 \mathrm{c}$ & $4.8 \mathrm{a}$ \\
\hline 6-Benzyladenine (6-BA) & $323.3 \mathrm{bc}$ & $17.7 \mathrm{~b}$ & $42.0 \mathrm{c}$ & $275.0 \mathrm{bc}$ & $864.1 \mathrm{a}$ & $4.6 \mathrm{a}$ \\
\hline trans-Zeatin $(t-Z)$ & $306.3 \mathrm{c}$ & $22.3 \mathrm{~b}$ & $33.0 \mathrm{c}$ & $244.0 \mathrm{~d}$ & $759.0 \mathrm{abc}$ & $5.1 \mathrm{a}$ \\
\hline MLE & $295.3 \mathrm{c}$ & $90.0 \mathrm{a}$ & $119.3 \mathrm{ab}$ & $243.3 \mathrm{~d}$ & $810.2 \mathrm{ab}$ & $6.9 \mathrm{a}$ \\
\hline$t-\mathrm{Z}$ & $391.3 \mathrm{a}$ & $31.7 \mathrm{~b}$ & $121.0 \mathrm{ab}$ & $316.7 \mathrm{a}$ & $886.2 \mathrm{a}$ & $4.5 \mathrm{a}$ \\
\hline MLE & $346.0 \mathrm{~b}$ & $34.7 \mathrm{~b}$ & $162.7 \mathrm{a}$ & $285.3 \mathrm{~b}$ & $876.4 \mathrm{a}$ & $5.7 \mathrm{a}$ \\
\hline Significance $^{\mathrm{x}}$ & $* * *$ & $* * *$ & * & *** & ** & NS \\
\hline
\end{tabular}

${ }^{\mathrm{z}} 1 \mathrm{~g}=0.0353 \mathrm{oz}$.

${ }^{y}$ Means within a column followed by different letters are significantly different by Fisher's protected least significant difference test at $P \leq 0.05$.

${ }_{\mathrm{NS}},{ }^{*}, * *, * * *$ Nonsignificant or significant at $0.05,0.01$, or 0.001 , respectively.

Table 2. Effects of four bimonthly $100-\mathrm{mL}(3.38 \mathrm{fl} \mathrm{oz})$ foliar or root applications of moringa leaf extract (MLE) (3.3\% w/v) and cytokinins $\left[25 \mathrm{mg} \cdot \mathrm{L}^{-1}(\mathrm{ppm})\right]$ on tomato biomass, number of lateral vegetative shoots, and plant height at the final harvest (84 $\mathrm{d}$ after planting).

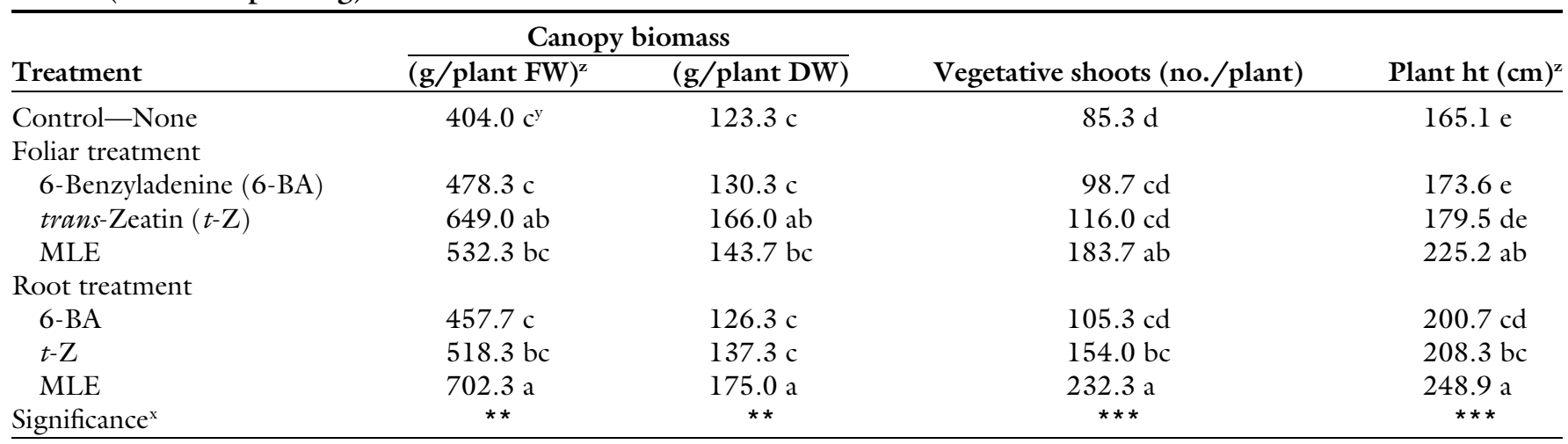

${ }^{\mathrm{z}} 1 \mathrm{~g}=0.0353 \mathrm{oz} ; \mathrm{l} \mathrm{cm}=0.3937$ inch.

${ }^{y}$ Means within a column followed by different letters are significantly different by Fisher's protected least significant difference test at $P \leq 0.05$.

$\mathrm{x} * *, * *$ Significant at $P \leq 0.01$ or 0.001 , respectively.

plants receiving root-applied MLE produced significantly more lateral vegetative shoots than plants in all other treatments, except foliar-applied MLE $(P \leq 0.001)$. Four treatments resulted in a net increase in the height of the cherry tomato plants above that of untreated control plants: rootapplied MLE (51\%), foliar-applied MLE (36\%), root-applied $t$-Z (26\%), and root-applied 6 -BA $(22 \%)(P \leq$ 0.001; Table 2). However, root-applied MLE significantly increased plant height to a greater degree than all other treatments except foliarapplied MLE $(P \leq 0.001)$.

EFFECTS OF MLE AND CYTOKININS ON LEAF CHLOROPHYLL AND $\beta$-CAROTENE CONCENTRATIONS. At the final harvest (84 d after planting), the relative chlorophyll concentrations of YFE leaves at descending positions in the canopy of the tomato plants were determined using a Minolta chlorophyll meter (SPAD-502), which gives the relative chlorophyll content of leaf samples. For comparison, concentrations of chlorophyll $a$ and $b$ in 80\% acetone extracts of YFE tomato leaves collected at the apex of the tomato plants were determined spectrophotometrically (Bruinsma, 1963). In this study, there was no significant correlation between the relative chlorophyll concentrations of YFE apical tomato leaves determined using the Minolta chlorophyll meter and the concentrations of chlorophyll $a$ or $b$ in these leaves determined by the method of Bruinsma (1963). Similarly, there was no correlation between the relative chlorophyll values obtained with the chlorophyll meter and the ratio of chlorophyll $a$ to $b$ determined by the method of Bruinsma (1963). However, there were significant correlations between the relative chlorophyll concentrations of the apical leaves and the FW and DW of the tomato plants $(r=0.91, P=0.0049$ and $r=0.93, P=$ 0.0023 , respectively) that were not obtained for chlorophyll $a$ or $b$ concentrations and plant FW or DW.

Foliar-applied $t-Z$ significantly increased the relative chlorophyll concentration of the apical leaf to a value greater than all other treatments, except root-applied MLE $(P \leq 0.001$; Table 3$)$. Foliar-applied $t$-Z and root-applied MLE increased the relative chlorophyll concentrations of leaves at the apex of the plants above that of untreated control plants $37 \%$ and $35 \%$, respectively $(P \leq 0.001)$. Both foliarapplied $t-Z$ and root-applied MLE significantly increased the relative chlorophyll concentrations of YFE leaves on lateral shoots located at $2 / 3$ the height of the plant $30 \%$ each compared with plants in all other treatments, except foliar-applied MLE $(P \leq 0.05$; Table 3). For YFE leaves on lateral 
Table 3. Effects of four bimonthly $100-\mathrm{mL}(3.38 \mathrm{fl} \mathrm{oz})$ foliar or root applications of moringa leaf extract (MLE) (3.3\%, w/v) and cytokinins $\left[25 \mathrm{mg} \cdot \mathrm{L}^{-1}(\mathrm{ppm})\right]$ on chlorophyll and $\beta$-carotene concentrations of young fully expanded tomato leaves at the final harvest ( $84 \mathrm{~d}$ after planting).

\begin{tabular}{|c|c|c|c|c|c|c|c|c|}
\hline \multirow[b]{2}{*}{ Treatment } & \multicolumn{4}{|c|}{$\begin{array}{l}\text { Relative chlorophyll concentrations } \\
\text { of leaves at descending levels of the } \\
\text { canopy (no. units) } \\
\text { zan }\end{array}$} & \multicolumn{4}{|c|}{$\begin{array}{c}\text { Apical leaf chlorophyll and } \\
\beta \text {-carotene }\left(\mathrm{mg} \cdot \mathrm{g}^{-1} \text { leaf } \mathrm{FW}\right)^{\mathrm{y}}\end{array}$} \\
\hline & Apex & $\begin{array}{c}2 / 3 \\
\text { Plant ht }\end{array}$ & $\begin{array}{c}1 / 3 \\
\text { Plant ht }\end{array}$ & Base & Chlorophyll $a$ & Chlorophyll $b$ & $\begin{array}{c}\text { Chlorophyll } \\
a / b \text { ratio }\end{array}$ & $\beta$-Carotene \\
\hline Control-None & $38.4 \mathrm{~cd}^{\mathrm{x}}$ & $31.5 \mathrm{~b}$ & $27.4 \mathrm{c}$ & $4.5 \mathrm{c}$ & $19.1 \mathrm{e}$ & $7.4 \mathrm{a}$ & 2.6 & $4.3 \mathrm{a}$ \\
\hline \multicolumn{9}{|l|}{ Foliar treatment } \\
\hline MLE & $43.9 \mathrm{c}$ & $36.7 \mathrm{ab}$ & $34.2 \mathrm{ab}$ & $13.3 \mathrm{a}$ & $26.3 \mathrm{ab}$ & $9.5 \mathrm{a}$ & 2.8 & $5.1 \mathrm{a}$ \\
\hline \multicolumn{9}{|l|}{ Root treatment } \\
\hline $6-\mathrm{BA}$ & $35.3 \mathrm{~d}$ & $32.3 \mathrm{~b}$ & $26.6 \mathrm{c}$ & $5.4 \mathrm{bc}$ & $24.7 \mathrm{bc}$ & $10.3 \mathrm{a}$ & 2.4 & $3.7 \mathrm{a}$ \\
\hline$t-\mathrm{Z}$ & $45.0 \mathrm{bc}$ & $33.2 \mathrm{~b}$ & $29.1 \mathrm{bc}$ & $9.1 \mathrm{~b}$ & $26.8 \mathrm{ab}$ & $12.0 \mathrm{a}$ & 2.2 & $4.3 \mathrm{a}$ \\
\hline MLE & $52.0 \mathrm{ab}$ & $40.6 \mathrm{a}$ & $33.7 \mathrm{ab}$ & $13.4 \mathrm{a}$ & $27.3 \mathrm{a}$ & $11.2 \mathrm{a}$ & 2.4 & $4.3 \mathrm{a}$ \\
\hline Significance $^{\mathrm{w}}$ & *** & * & ** & $* * *$ & ** & NS & NS & NS \\
\hline
\end{tabular}

${ }^{2}$ Relative chlorophyll concentrations were determined with a chlorophyll meter.

${ }^{y}$ Chlorophyll $a$ and $b$ and $\beta$-carotene concentrations were determined spectrophotometrically in leaf acetone extracts $($ Bruinsma, 1963$) ; 1$ mg. $\mathrm{g}^{-1}=1000 \mathrm{ppm}$.

${ }^{x}$ Means within a column followed by different letters are significantly different by Fisher's protected least significant difference test at $P \leq 0.05$.

${ }^{\mathrm{N}} \mathrm{NS},{ }^{*},{ }^{*},{ }^{* *}$ Nonsignificant or significant at $P \leq 0.05,0.01$, or 0.001 , respectively.

shoots located at $1 / 3$ the height of the plant, relative chlorophyll content was significantly increased above that of the untreated control plants by foliarapplied $t-Z$ (36\%) and MLE (25\%) and root-applied MLE (23\%) ( $P \leq 0.01$; Table 3 ). Four treatments significantly increased the relative chlorophyll concentration of leaves at the base of the plant above that of basal leaves of the untreated control plants: foliarapplied $t$-Z ( 1 -fold) and MLE (2fold) and root-applied $t-Z$ ( 1 -fold) and MLE (2-fold) $(P \leq 0.001$; Table $3)$. However, of these four treatments, only foliar- and root-applied MLE resulted in greater leaf relative chlorophyll concentrations than those observed in all other treatments $(P \leq$ $0.001)$. Quantifying leaf chlorophyll concentration using the method of Bruinsma (1963) for comparison, all treatments increased YFE apical leaf chlorophyll a concentrations compared with untreated control plants $(P \leq$ 0.01 ; Table 3 ); whereas no treatment increased the concentration of chlorophyll $b$ to a value greater than that of the untreated control plants (Table 3 ). Similarly, there were no treatment effects on the ratio of chlorophyll $a$ to $b$ (Table 3 ). There were also no treatment effects on leaf concentrations of $\beta$-carotene (Table 3 ).

EFFECTS OF MLE AND CYTOKININS ON LEAF METABOLITE CONCENTRATIONS. Despite significant differences in the relative chlorophyll and chlorophyll a concentrations in apical YFE tomato leaves in response to the different treatments, there were no treatment effects on apical leaf concentrations of soluble sugars (Table 4). Foliar- and root-applied MLE and foliar-applied $t$-Z significantly increased the protein concentrations of apical YFE tomato leaves 2.3-, 2.6-, and 2.2-fold, respectively, with rootapplied MLE increasing tomato leaf protein concentrations significantly more than all other treatments, except foliar-applied MLE and $t-Z$ $(P \leq 0.01$; Table 4$)$. Foliar and root-applied MLE increased apical YFE leaf proline concentrations 2-fold compared with the apical leaf of the untreated control plants $(P \leq 0.01$; Table 4). Although not as effective as MLE, foliar-applied $t$-Z also increased leaf proline concentrations to a value $40 \%$ greater than that of the untreated control plants $(P \leq 0.01)$. All treatments significantly increased tomato leaf arginine concentrations compared with the untreated control plants, with the greatest increase $(69 \%)$ in response to foliar-applied MLE $(P \leq 0.01$; Table 4). Total antioxidant concentrations were significantly greater in YFE leaves from cherry tomato plants treated with foliar-applied $t-Z \quad(36 \%)$ and MLE (35\%) and root-applied 6-BA (29\%) than leaves of untreated control plants $(P \leq 0.05$; Table 4$)$. Total phenols were significantly greater in leaves of plants treated with root-applied $t-Z$ (60\%) and foliar-applied MLE (26\%) or $t-\mathrm{Z}(18 \%)$ than the untreated control plants, with leaves from plants treated with root-applied $t-\mathrm{Z}$ having the greatest concentration of total phenols compared with plants in all other treatments $(P \leq 0.001$; Table 4$)$.

EFFECTS OF MLE AND CYTOKININS ON TOMATO FRUIT QUALITY. All treatments increased fruit soluble sugar concentrations to a value greater than the untreated control plants, except root-applied $t$-Z $(P \leq 0.001$; Table 5$)$. The three better treatments were foliar-applied MLE and $t-Z$ and root-applied MLE; fruit from plants in these treatments had equal soluble sugar concentrations that were 1.5to 1.6-fold greater than fruit from the untreated control plants. Fruit soluble protein concentrations were greater than the untreated control for all treatments, except root-applied 6-BA $(P \leq 0.001$; Table 5 ). The greatest soluble protein concentration was found in fruit from plants treated with root-applied $t-Z$, but it was not significantly greater than fruit from plants treated with root-applied MLE. Fruit from tomato plants treated with root-applied $t-Z$ and MLE had 4.3 - and 3.5-fold more protein than fruit from untreated control plants, respectively. Fruit from plants in all treatments had greater total antioxidant concentrations than fruit from the untreated control plants $(P \leq$ 0.001 ; Table 5 ). The greatest concentration was achieved with a foliar application of $t$ - Z (2-fold) compared with fruit from the untreated control plants, followed by root-applications of 6-BA or MLE, both of which increased fruit antioxidant concentrations 1.7-fold above that of fruit from 


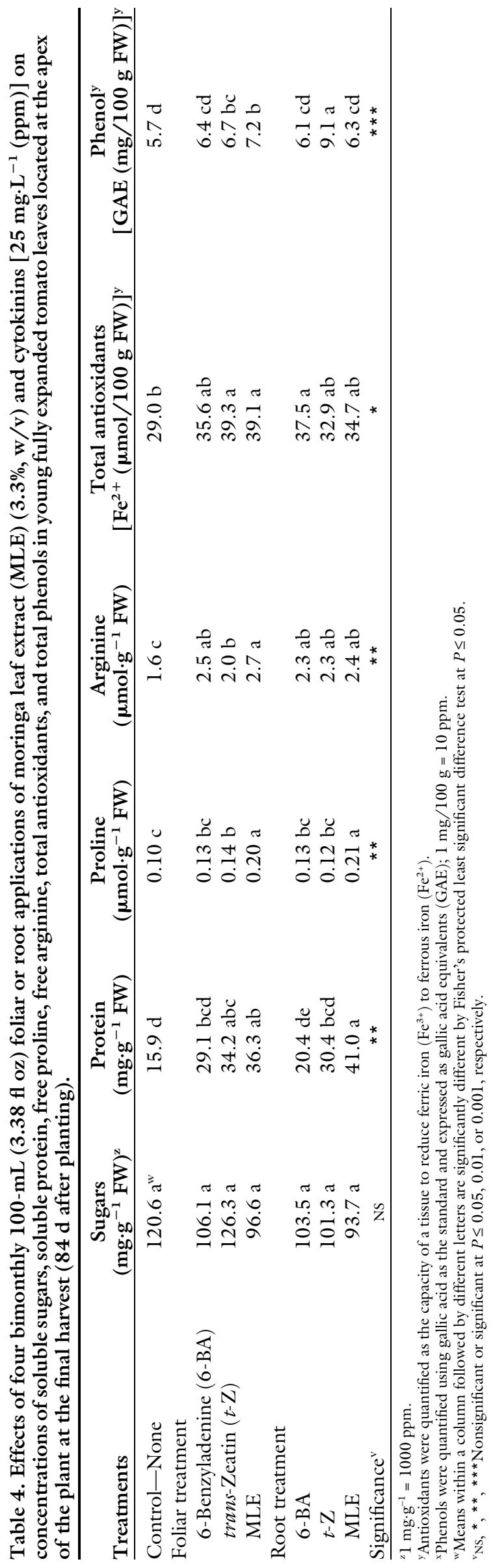

untreated control plants, but not more than root-applied $t-Z$, which increased fruit antioxidant concentrations 1.5fold more than untreated control fruit. Lycopene concentrations in the fruit were also significantly increased by all treatments relative to fruit from the untreated control plants $(P \leq 0.001$; Table 5). Root-applied $t-Z$ was the most effective treatment for increasing fruit lycopene concentrations, a 5.2 -fold increase relative to fruit from untreated control plants, but it was not significantly more effective than foliar-applied $t$ - $Z$ or rootapplied MLE, which increased tomato fruit lycopene concentrations 4.9- and 4.2-fold, respectively, relative to fruit from the untreated control plants. No treatment had an effect on the total phenol concentrations of the fruit (Table 5).

MORINGA LEAF HORMONE CONCENTRATIONS. The pool of cytokinins in moringa leaves was predominantly composed of the cytokinin nucleosides iPA, $t$-ZR, $c$-ZR, and dhZR (Table 6). Moringa leaf concentrations of $c$-ZR and iPA decreased from midApril to mid-May, but increased again to their greatest concentrations in midJune. The cytokinin bases $t-\mathrm{Z}$ and $c-\mathrm{Z}$, and $\mathrm{dhZ}$ were not detected on any sampling date, whereas $2 \mathrm{iP}$ was present at less than $2 \mathrm{ng} \cdot \mathrm{g}^{-1} \mathrm{DW}$ on all dates. The reversible glucosylated forms of trans- and cis-zeatin ( $t$-ZOG and $c$-ZOG) were not detected in moringa leaves from April through June. IAA was only detected in moringa leaves collected in April; IBA was never detected (Table 6). The most common forms of auxin in moringa leaves on all sample dates were the conjugates of IAA with aspartate (IAA-Asp) and glutamate (IAA-Glu), with IAA-Asp present in moringa leaves at a concentration 28- to 44-fold greater than IAA-Glu. Conjugation of IAA with alanine or leucine was not detected in moringa leaf samples from April through June. Of the 14 GAs analyzed, only $\mathrm{GA}_{19}$, a precursor of $\mathrm{GA}_{1}$ biosynthesis via the intermediate $\mathrm{GA}_{20}$, was present in a measureable quantity (12 $\mathrm{ng} \cdot \mathrm{g}^{-1} \mathrm{DW}$ in June leaf samples only); $\mathrm{GA}_{24}$, a precursor of $\mathrm{GA}_{4}$, was also detected in June at less $4 \mathrm{ng} \cdot \mathrm{g}^{-1}$ DW leaf tissue (Table 6). cis$\mathrm{ABA}$ and most of its metabolites were present in all moringa leaf samples (Table 6). The conjugated form of $\mathrm{ABA}$ (ABAGE) was present at 
Table 5. Effects of four bimonthly $100-\mathrm{mL}(3.38 \mathrm{fl} \mathrm{oz})$ foliar or root applications of moringa leaf extract (MLE) $(3.3 \%, \mathrm{w} / \mathrm{v})$ and cytokinins $\left[25 \mathrm{mg} \cdot \mathrm{L}^{-1}(\mathrm{ppm})\right]$ on tomato fruit concentrations of soluble sugars, soluble protein, total antioxidants, lycopene, and total phenols at the final harvest ( $84 \mathrm{~d}$ after planting).

\begin{tabular}{|c|c|c|c|c|c|}
\hline Treatment & $\begin{array}{c}\text { Sugars } \\
\left(\mathrm{mg} \cdot \mathrm{g}^{-1} \mathrm{FW}\right)^{\mathrm{z}}\end{array}$ & $\begin{array}{c}\text { Protein } \\
\left(\mathrm{mg}^{-1} \mathrm{~g}^{-1} \mathrm{FW}\right)\end{array}$ & $\begin{array}{c}\text { Total antioxidants } \\
{\left[\mathrm{Fe}^{2+}\left(\mu \mathrm{mol} / 100 \mathrm{~g} \mathrm{FW}^{\mathrm{z}}\right]^{\mathrm{y}}\right.}\end{array}$ & $\begin{array}{c}\text { Lycopene } \\
\left(\mu \mathrm{g} \cdot \mathrm{g}^{-1} \mathrm{FW}\right)^{\mathrm{z}}\end{array}$ & $\begin{array}{c}\text { Phenols } \\
{[\text { GAE }(\mathrm{mg} / 100 \mathrm{~g} \mathrm{FW})]^{\mathrm{x}}}\end{array}$ \\
\hline Control-None & $125.3 c^{w}$ & $3.9 \mathrm{e}$ & $25.0 \mathrm{e}$ & $3.1 \mathrm{~d}$ & $5.3 \mathrm{a}$ \\
\hline \multicolumn{6}{|l|}{ Foliar treatment } \\
\hline $\begin{array}{l}\text { 6-Benzyladenine } \\
\text { (6-BA) }\end{array}$ & $178.0 \mathrm{ab}$ & $8.5 \mathrm{~cd}$ & $35.6 \mathrm{~cd}$ & $11.8 \mathrm{bc}$ & $6.4 \mathrm{a}$ \\
\hline trans-Zeatin $(t-Z)$ & $187.5 \mathrm{a}$ & $10.0 \mathrm{bc}$ & $51.1 \mathrm{a}$ & $15.3 \mathrm{ab}$ & $6.5 \mathrm{a}$ \\
\hline 6-BA & $176.2 \mathrm{ab}$ & $5.0 \mathrm{de}$ & $43.1 \mathrm{~b}$ & $8.5 \mathrm{c}$ & $6.2 \mathrm{a}$ \\
\hline$t-\mathrm{Z}$ & $152.3 \mathrm{bc}$ & $16.6 \mathrm{a}$ & $38.6 \mathrm{bc}$ & $16.2 \mathrm{a}$ & $7.1 \mathrm{a}$ \\
\hline MLE & $184.5 \mathrm{a}$ & $13.8 \mathrm{ab}$ & $41.4 \mathrm{~b}$ & $13.6 \mathrm{ab}$ & $6.1 \mathrm{a}$ \\
\hline Significance $^{\mathrm{v}}$ & $* * *$ & $* * *$ & $* * *$ & $* * *$ & NS \\
\hline
\end{tabular}

${ }^{\mathrm{z}} 1 \mathrm{mg} \cdot \mathrm{g}^{-1}=1000 \mathrm{ppm} ; \mathrm{l} \mu \mathrm{g} \cdot \mathrm{g}^{-1}=1 \mathrm{ppm}$.

y Antioxidants were quantified as the capacity of a tissue to reduce ferric iron $\left(\mathrm{Fe}^{3+}\right)$ to ferrous iron $\left(\mathrm{Fe}^{2+}\right)$.

'Phenols were measured using gallic acid as the standard and expressed as gallic acid equivalents (GAE); $1 \mathrm{mg} / 100 \mathrm{~g}=10 \mathrm{ppm}$.

${ }^{\text {w}}$ Means within a column followed by different letters are significantly different by Fisher's protected least significant difference test at $P \leq 0.05$

${ }^{\mathrm{N}} \mathrm{NS},{ }^{* * *}$ Nonsignificant or significant at $P \leq 0.001$, respectively.

concentrations $41 \%, 99 \%$, and $73 \%$ greater than the concentrations of ABA in moringa leaves collected in April, May, and June, respectively. The catabolites derived from the $8^{\prime}$ hydroxylation pathway, PA, and DPA, were present in moringa leaves at all sampling dates. PA was the ABA catabolite in the greatest concentration. Its concentration was more than 3 -fold greater than the concentration of $\mathrm{ABA}$ in April and June. Phaseic acid is further reduced to DPA, which was detected at much lower concentrations than PA on all sampling dates. In addition, traces of other catabolites that are products of the $7^{\prime}$-hydroxylation and $9^{\prime}$-hydroxylation pathways; i.e., 7'-OH-ABA and neoPA, respectively, were identified. It should be noted that $t$-ABA, which was also detected, is a product of isomerisation of natural ABA under ultraviolet light (Plant Biotechnology Institute, National Research Council of Canada, unpublished data). With the exception of DPA, which decreased in concentration from April to June, concentrations of $\mathrm{ABA}$ and its other metabolites were relatively similar from April through June.

\section{Discussion}

In this single experiment, the MLE and cytokinin $t-Z$ had similar positive effects on tomato plant physiology, growth, and productivity. Root-applied MLE provided more positive results than foliar-applied MLE, with the opposite case for $t-Z$. The data documented that cytokinins and MLE, a putative source of cytokinins (Foidl et al., 2001), increased the reproductive development and productivity of tomato plants, with MLE and $t-Z$ decidedly more efficacious than 6-BA. All treatments (except root-applied 6$\mathrm{BA}$ ) increased the total number of flowers produced by the tomato plants relative to the untreated control plants, but only foliar-applied MLE increased the number of lateral floral shoots that developed per plant and the number of flowers per plant remaining at the final harvest (84 d after planting) compared with the untreated control plants. All treatments (except root-applied 6-BA) significantly increased the total number of fruit produced per plant through the final harvest compared with the untreated control plants, but only four treatments significantly increased yield as grams of fruit per plant, foliarapplied 6-BA and MLE and rootapplied $t-Z$ and MLE. Fruit size decreased with progressively later harvest dates, but treatments that increased yield did not cause a significant reduction in fruit size. In addition, the cytokinin and MLE treatments enhanced tomato fruit quality parameters. All treatments increased fruit total soluble sugars (except root-applied $t-Z$ ), soluble proteins (except root-applied 6-BA), total antioxidants, and lycopene. These positive effects on tomato fruit quality contribute to the improved nutritional value of the fruit (protein) and the health benefits associated with antioxidants and lycopene that are valued by consumers (Dewanto et al.,
2002; Giovannucci, 1999). Treatments that can increase these metabolites might provide an economic advantage in the marketing of the fruit.

The cytokinin and MLE treatments also increased the vegetative growth of the tomato plants. Whereas root-applied MLE resulted in greater canopy biomass (both FW and DW), more lateral vegetative shoots, and greater plant height than root-applied $t$-Z, foliar-applied MLE, and $t$-Z increased canopy biomass, number of lateral vegetative shoots, and plant height equally. 6-BA increased only plant height above that of the untreated control plants. The treatments also increased leaf chlorophyll concentrations. Root-applied MLE increased relative chlorophyll concentrations in leaves from the apex to the base of the tomato plant and increased apical leaf chlorophyll $a$ concentration above that of apical leaves from the untreated control plants. Foliar-applied $t-Z$ increased relative chlorophyll concentrations in leaves of lateral shoots located at the apex, $2 / 3$ and $1 / 3$ the height of the plant, but not the basal leaves, and was less effective in increasing chlorophyll a than root-applied MLE. In this study, there were no significant correlations between the relative chlorophyll values of the apical leaves obtained with the Minolta chlorophyll meter and the concentrations of chlorophyll $a$ or $b$ in apical leaves determined after chemical extraction according to the method of Bruinsma (1963). Netto et al. (2005) reported 
Table 6. Concentrations of cytokinins, auxin, gibberellins (GAs), and abscisic acid and their metabolites in young fully expanded moringa leaves collected in April, May, and June.

\begin{tabular}{|c|c|c|c|c|}
\hline \multirow{2}{*}{\multicolumn{2}{|c|}{ Hormone abbreviation }} & \multicolumn{3}{|c|}{ 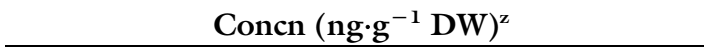 } \\
\hline & & April & May & June \\
\hline \multicolumn{5}{|c|}{ Cytokinins } \\
\hline trans-Zeatin & $t-\mathrm{Z}$ & $\mathrm{nd}^{\mathrm{y}}$ & nd & nd \\
\hline cis-Zeatin & $c-\mathrm{Z}$ & nd & nd & nd \\
\hline Dihydrozeatin & dhZ & nd & nd & nd \\
\hline Isopentenyladenine & $2 \mathrm{iP}$ & $<2$ & $<2$ & $<2$ \\
\hline trans-Zeatin riboside & $t-\mathrm{ZR}$ & 4 & 2 & 4 \\
\hline cis-Zeatin riboside & $c-\mathrm{ZR}$ & 163 & 53 & 326 \\
\hline Dihydrozeatin riboside & dhZR & 3 & $<2$ & $<2$ \\
\hline Isopentenyladenosine & iPA & 317 & 132 & 466 \\
\hline trans-Zeatin-O-glucoside & $t$-ZOG & nd & nd & nd \\
\hline cis-Zeatin-O-glucoside & $c$-ZOG & nd & nd & nd \\
\hline \multicolumn{5}{|c|}{ Auxins } \\
\hline Indole-3-acetic acid & IAA & 37 & nd & nd \\
\hline $\mathrm{N}$-(Indole-3-yl-acetyl)-aspartic acid & IAA-Asp & 6,227 & 6,829 & 7,811 \\
\hline $\mathrm{N}$-(Indole-3-yl-acetyl)-glutamic acid & IAA-Glu & 140 & 214 & 227 \\
\hline $\mathrm{N}$-(Indole-3-yl-acetyl)-alanine & IAA-Ala & nd & nd & nd \\
\hline $\mathrm{N}$-(Indole-3-yl-acetyl)-leucine & IAA-Leu & nd & nd & nd \\
\hline Indole-3-butyric acid & IBA & nd & nd & nd \\
\hline \multicolumn{5}{|c|}{ Gibberellins } \\
\hline Gibberellin 1 & $\mathrm{GA}_{1}$ & nd & nd & nd \\
\hline Gibberellin 3 & $\mathrm{GA}_{3}$ & nd & nd & nd \\
\hline Gibberellin 4 & $\mathrm{GA}_{4}$ & nd & nd & nd \\
\hline Gibberellin 7 & $\mathrm{GA}_{7}$ & nd & nd & nd \\
\hline Gibberellin 8 & $\mathrm{GA}_{8}$ & nd & nd & nd \\
\hline Gibberellin 9 & $\mathrm{GA}_{9}$ & nd & nd & nd \\
\hline Gibberellin 19 & $\mathrm{GA}_{19}$ & nd & nd & 12 \\
\hline Gibberellin 20 & $\mathrm{GA}_{20}$ & nd & nd & nd \\
\hline Gibberellin 24 & $\mathrm{GA}_{24}$ & nd & nd & $<4$ \\
\hline Gibberellin 29 & $\mathrm{GA}_{29}$ & nd & nd & nd \\
\hline Gibberellin 34 & $\mathrm{GA}_{34}$ & nd & nd & nd \\
\hline Gibberellin 44 & $\mathrm{GA}_{44}$ & nd & nd & nd \\
\hline Gibberellin 51 & $\mathrm{GA}_{51}$ & nd & nd & nd \\
\hline \multirow{2}{*}{\multicolumn{5}{|c|}{ Abscisic acid }} \\
\hline & & & & \\
\hline cis-Abscisic acid & $\mathrm{ABA}$ & 844 & 804 & 868 \\
\hline Abscisic acid-glucose ester & ABAGE & 1,189 & 1,599 & 1,500 \\
\hline Dihydrophaseic acid & DPA & 894 & 306 & 255 \\
\hline Phaseic acid & PA & 3,556 & 2,035 & 2,792 \\
\hline 7'-Hydroxy-abscisic acid & 7’OH-ABA & 15 & $<7$ & 32 \\
\hline neo-Phaseic acid & neo-PA & 46 & 52 & 64 \\
\hline trans-Abscisic acid & $t-\mathrm{ABA}$ & 11 & nd & 32 \\
\hline
\end{tabular}

${ }^{\mathrm{z}} 1 \mathrm{ng} \cdot \mathrm{g}^{-1}=1 \mathrm{ppb}$.

${ }^{y}$ Not detected.

that a polynomial quadratic mathematical model was required to describe this relationship in coffee robusta leaves (Coffea canephora). Thus, in the present study no units could be reported for relative chlorophyll values determined with the chlorophyll meter. The significant Pearson product-moment correlation coefficients for relative chlorophyll content of the apical leaves and plant FW and DW at harvest could reflect the relationship between leaf chlorophyll content and photosynthetic processes or leaf nitrogen concentrations and their effect on plant growth. Tomato plants treated with 6-BA and untreated control plants had lower leaf relative chlorophyll values and exhibited less vegetative growth and biomass accumulation than tomato plants in other treatments.

Foliar-applied $t-Z$ and MLE and root-applied MLE were the only treatments that increased leaf protein and proline concentrations to values significantly greater than the untreated control plants. Increased leaf proline concentrations might be beneficial to tomato plant growth and yield because of proline's well-known role as a compatible solute that protects plants during osmotic stresses (Verbruggen and Hermans, 2008). Leaf arginine concentrations were increased by all treatments to values significantly greater than the untreated control plants. Arginine is important for its role in nitrogen transport and storage and as a precursor for polyamine and nitric oxide biosynthesis, both of which are critical 
components of the plant's capacity to survive abiotic stresses (Shi and Chan, 2013). Leaf concentrations of antioxidants and phenols were significantly increased relative to the untreated control plants by foliar-applied $t-Z$ and MLE. Root-applied 6-BA increased leaf antioxidant concentrations relative to leaves of the untreated control plants, whereas root-applied $t-\mathrm{Z}$ increased leaf total phenol concentrations. Increased leaf concentrations of antioxidants or phenols would improve productivity by protecting photosynthesis from reactive oxygen species and free radicals generated by processes preventing photoinhibition, by protecting plant cells from the harmful effects of ultraviolet radiation and by protecting the plant in response to pathogen or insect attack or wounding (Korkina, 2007).

The growth-promoting effects of MLE are likely due to the pool of cytokinins in moringa leaves, which was composed predominantly of the ribosylated cytokinins isopentenyladenosine and $c$-ZR, along with trace amounts of $t$-ZR and dhZR. Cytokinin ribosides not only serve as intermediates in cytokinin biosynthesis, but also as transport forms of cytokinins, with $c$-ZR and iPA involved in long-distance signaling in the phloem and $t$-ZR in the xylem (Hirose et al., 2008; Sakakibara, 2006). In addition, transport proteins for the uptake of ribosylated cytokinins are present in plant cell membranes, which would facilitate uptake of exogenously applied cytokinin ribosides (Hirose et al., 2008; Sakakibara, 2006). Moringa leaf concentrations of $c$-ZR and iPA decreased from mid-April to mid-May, but increased again to their greatest concentration in mid-June. In contrast, cytokinin bases, zeatin (both cisand trans-), dhZ, and $2 \mathrm{iP}$, were not detected or were present at less than $2 \mathrm{ng} \cdot \mathrm{g}^{-1}$ DW in moringa leaves. Indole-3-acetic acid was only present in moringa leaves collected in April and not detected in May or June, consistent with the lack of detection of the reversibly inactive glucosylated forms of IAA and the presence on all collection dates of IAA-aspartic acid and IAA-glutamic acid, which are considered the starting points for IAA catabolism (LudwigMuller, 2011; Woodward and Bartel, 2005). Taken together, these results further support that increased tomato plant growth and yield in response to exogenously applied MLE was due to their cytokinin titers. This interpretation is supported further, because active GAs, which include $\mathrm{GA}_{1}, \mathrm{GA}_{3}$, $\mathrm{GA}_{4}$, and $\mathrm{GA}_{7}$ (Yamaguchi, 2008), were not detected in MLE. Only $\mathrm{GA}_{19}$ was detected at a modest level (12 ng. $\mathrm{g}^{-1} \mathrm{DW}$ leaf tissue), but only in June, along with $\mathrm{GA}_{24}$ at a concentration less than $4 \mathrm{ng} \cdot \mathrm{g}^{-1} \mathrm{DW}$ leaf tissue. Both are intermediates in the synthesis of active GAs, $\mathrm{GA}_{1}$ and $\mathrm{GA}_{4}$, respectively (Yamaguchi, 2008). The growth inhibitor, $\mathrm{ABA}$, was present, but at much lower concentrations than its inactive glucose ester or catabolites. The presence of ABA in the MLE clearly did not inhibit vegetative or reproductive growth of the tomato plants in this experiment, but might have contributed to the increased concentrations of proline and antioxidants, a response to exogenously applied ABA that contributes to protecting plants from osmotic stresses.

Taken together, the results of this research provided evidence that MLE improved both vegetative and reproductive development of tomato plants, including increased fruit yield and quality. However, the results reported herein are from a single experiment that was not repeated. Therefore, care must be taken in interpreting the significance of the results until they are replicated in a separate experiment. To this point, based on these preliminary results, further research with the goal of developing MLE for use in commercial crop production, especially organic crop production would appear warranted. The goal of publishing these results was to stimulate additional research on the use of cytokinins in tomato production in general and in particular MLE for organic horticultural crop production.

\section{Literature cited}

Afzal, I., B. Hussain, S.M.A. Basra, and H. Rehman. 2012. Priming with moringa leaf extract reduces imbibitional chilling injury in spring maize. Seed Sci. Technol. 44(2):271-276.

Agarwal, A., H. Shen, S. Agarwal, and A.V. Rao. 2001. Lycopene content of tomato products: Its stability, bioavailability and in vivo antioxidant properties. J. Med. Food. 4:9-15.
Baker, K.F. 1957. University of California soil mixes. California Agr. Expt. Sta. Manual No. 23.

Basra, S.M.A., M.N. Iftikhar, and I. Afzal. 2011. Potential of moringa (Moringa oleifera) leaf extract as priming agent for hybrid maize seeds. Intl. J. Agr. Biol. 13(6): 1006-1010.

Bayer CropScience. 2003. Ethrel. 8 Apr. 2016. <http://msds.plantprod.com/ document/167>.

Bradford, M.M. 1976. A rapid and sensitive method for the quantitation of microgram quantities of protein utilizing the principle of protein-dye binding. Anal. Biochem. 72(1-2):248-254.

Bruinsma, J. 1963. The quantitative analysis of chlorophylls $a$ and $b$ in plant extracts. Photochem. Photobiol. 2(2): 241-249.

Chinard, F.P. 1952. Photometric estimation of proline and ornithine. J. Biol. Chem. 199:91-95.

Chiwocha, S.D.S., A.J. Cutler, S.R. Abrams, S.J. Ambrose, J. Yang, A.R.S. Ross, and A.R. Kermode. 2005. The etrl-2 mutation in Arabidopsis thaliana affects the abscisic acid, auxin, cytokinin and gibberellin metabolic pathways during maintenance of seed dormancy, moist-chilling and germination. Plant J. 42(1):35-48.

Chiwocha, S.D.S., S.R. Abrams, S.J. Ambrose, A.J. Cutler, M. Loewen, A.R.S. Ross, and A.R. Kermode. 2003. A method of profiling classes of plant hormones and their metabolites using liquid chromatography-electrospray ionization tandem mass spectrometry: An analysis of hormone regulation of thermodormancy of lettuce (Lactuca sativa L.) seeds. Plant J. 35(3):405-417.

Dewanto, V., X. Wu, K.K. Adom, and R.H. Liu. 2002. Thermal processing enhances the nutritional value of tomatoes by increasing total antioxidant activity. J. Agr. Food Chem. 50(10):3010-3014.

El-Otmani, M., C.W. Coggins, Jr., M. Agusti, and C.J. Lovatt. 2000. Plant growth regulators in citriculture: World current uses. Crit. Rev. Plant Sci. 19(5): 395-447.

Food and Agriculture Organization of the United Nations. 2015. Browse data by domain. Production. Prices. 8 Apr. 2016. $<$ http://faostat3.fao.org/home/E >.

Foidl, N., H.P.S. Makkar, and K. Becker. 2001. The potential of Moringa oleifera for agricultural and industrial uses, p. 4576. In: L.J. Fuglie (ed.). The miracle tree: The multiple attributes of moringa. CTA Publ., Wageningen, The Netherlands. 
Fuglie, L.J. 1999. The miracle tree: Moringa oleifera: Natural nutrition for the tropics. Church World Serv., Dakar, Senegal.

Garming, H. 2014. Tomatoes are the superlative vegetables: Global per capita consumption is 20 kilograms per year. 15 Dec. 2015. <http://www.agribenchmark. org/agri-benchmark/did-you-know/ einzelansicht/artikel//tomatoes-are. html>.

Giovannucci, E. 1999. Tomatoes, tomatobased products, lycopene, and cancer: Review of the epidemiologic literature. J. Natl. Cancer Inst. 91(4):317-331.

Greene, C. 2013a. Organic production, Documentation. 8 Apr. 2016. <http:// www.ers.usda.gov/data-products/organicproduction/documentation.aspx $>$.

Greene, C. 2013b. Organic production, Overview, Data Set, National Tables 2 and 3. 8 Apr. 2016. <http://www.ers.usda. gov/data-products/organic-production. aspx\#25762>.

Halvorsen, B.L., K. Holte, M.C.W. Myhrstad, I. Barikmo, E. Hvattum, S.F. Remberg, A.B. Wold, K. Haffner, H. Baugerod, L.F. Andersen, J.O. Moskaug, D.R. Jacobs, Jr., and R. Blomhoff. 2002. A systematic screening of total antioxidants in dietary plants. J. Nutr. 132(3):461-471.

Hirose, N., K. Takei, T. Kuroha, T. Kamada-Nobusada, H. Hayashi, and H. Sakakibara. 2008. Regulation of cytokinin biosynthesis, compartmentalization and translocation. J. Expt. Bot. 59(1):75-83.

Hoagland, D.R. and D.I. Arnon. 1950. The water culture for growing plants without soil. California Agr. Expt. Sta. Circ. 347.

Javid, M.G., A. Sorrooshzadeh, F. Morandi, S.A.M.M. Sanavy, and I. Allahdadi. 2011. The role of phytohormones in alleviating salt stress in crop plants. Austral. J. Crop Sci. 5(6):726-734.

Korkina, L.G. 2007. Phenylpropanoids as naturally occurring antioxidants: From plant defense to human health. Cell. Mol. Biol. 53(1):15-25.

Lovatt, C.J. 2006. Plant growth regulators for avocado production. California
Avocado Soc. 2005-2006 Yrbk. 88:8191.

Ludwig-Muller, J. 2011. Auxin conjugates: Their role for plant development and in evolution of land plants. J. Expt. Bot. 62(6):1757-1773.

Makkar, H.P.S. and K. Becker. 1996. Nutritional value and antinutritional components of whole and ethanol extracted Moringa oleifera leaves. Anim. Feed Sci. Technol. 63(1-4):211-228.

Mekonnen, Y. 1999. Effects of ethanol extract of Moringa stenopetala leaves on guinea-pig and mouse smooth muscle. Phytother. Res. 13:442-444.

MSTAT Development Team. 1989. MSTAT user's guide: A microcomputer program for the design management and analysis of agronomic research experiments. Michigan State Univ., East Lansing, MI.

Naeve, L. 2015. Commodities and products, Tomatoes. 10 Nov. 2015. <http:// www.agmrc.org/commodities_products/ vegetables/tomatoes/>.

Nagar, P.K., R.I. Iyer, and P.K. Sircar. 1982. Cytokinins in developing fruits of Moringa pterygosperma Gaertn. Physiol. Plant. 55(1):45-50.

Netto, A.T., E. Campostrini, J.G. Oliveira, and R.E. Bressan-Smith. 2005. Photosynthetic pigments, nitrogen, chlorophyll a fluorescence and SPAD-502 readings in coffee leaves. Sci. Hort. 104:199-209.

Nouman, W., M.T. Siddiqui, and S.M.A. Basra. 2012. Moringa oleifera leaf extract: An innovative priming tool for rangeland grasses. Turk. J. Agr. For. 36:65-75.

Paul, J. and B. Hennig. 2011. A world map of organic agriculture. European J. Social Sci. 24(3):360-369.

Ramachandran, C., K.V. Peter, and P.K. Gopalakrishnan. 1980. Drumstick (Moringa oleifera): A multipurpose Indian vegetable. Econ. Bot. 34(3):276-283.

Sakakibara, H. 2006. Cytokinins: Activity, biosynthesis, and translocation. Annu. Rev. Plant Biol. 57:431-449.

Ross, A.R.S., S.J. Ambrose, A.J. Cutler, J.A. Feurtado, A.R. Kermode, K. Nelson,
R. Zhou, and S.R. Abrams. 2004. Determination of endogenous and supplied deuterated abscisic acid in plant tissues by high-performance liquid chromatographyelectrospray ionization tandem mass spectrometry with multiple reaction monitoring. Anal. Biochem. 329(2):324-333.

Shi, H.-T. and Z.-L. Chan. 2013. In vivo role of Arabidopsis arginase in arginine metabolism and abiotic stress response. Plant Signal. Behav. 8(5):e24138.

Spanos, G.A. and R.E. Wrolstad. 1990. Influence of processing and storage on the phenolic composition of Thompson seedless grape juice. J. Agr. Food Chem. 38(7): 1565-1571.

Stoller Enterprises. n.d. Stoller ${ }^{\circledR}$ X-Cyte specimen label. 15 Mar. 2016. <http:// www.cdms.net/LDat/ld6LB001.pdf>.

Valent BioSciences. 2014. Activol. 15 Mar. 2106. <http://pgr.valentbiosciences. com/valent-biosciences-corporationbiorational-crop-enhancement/products/ activol>.

van Pilsum, J.F., R.P. Martin, E. Kito, and J. Hess. 1956. Determination of creatine, creatinine, arginine, guanidinoacetic acid, guanidine, and methylguanidine in biological fluids. J. Biol. Chem. 222(1): 225-235.

Verbruggen, N. and C. Hermans. 2008. Proline accumulation in plants: A review. Amino Acids 35(4):753-759.

Woodward, A.W. and B. Bartel. 2005. Auxin: Regulation, action and interaction. Ann. Bot. 95(5):707-735.

Yamaguchi, S. 2008. Gibberellin metabolism and its regulation. Annu. Rev. Plant Biol. 59:225-251.

Yasmeen, A., S.M.A. Basra, M. Farooq, H. Rehman, N. Hussain, and H.R. Athar. 2013. Exogenous application of moringa leaf extract modulates the antioxidant enzyme system to improve wheat performance under saline conditions. Plant Growth Regulat. 69(3):225-233.

Yemm, E.W. and A.J. Willis. 1954. Estimation of carbohydrates in plant extracts by anthrone. Biochem. J. 57(3):508-514. 